Bond University

Research Repository

\title{
Championing family business issues to influence public policy: Evidence from Australia
}

Craig, Justin B.; Moores, Kenneth

Published in:

Family Business Review

DOI:

$10.1177 / 0894486510366426$

Licence:

CC BY-NC-ND

Link to output in Bond University research repository.

Recommended citation(APA):

Craig, J. B., \& Moores, K. (2010). Championing family business issues to influence public policy: Evidence from Australia. Family Business Review, 23(2), 170-180. https://doi.org/10.1177/0894486510366426

\footnotetext{
General rights

Copyright and moral rights for the publications made accessible in the public portal are retained by the authors and/or other copyright owners and it is a condition of accessing publications that users recognise and abide by the legal requirements associated with these rights.
}

For more information, or if you believe that this document breaches copyright, please contact the Bond University research repository coordinator. 


\title{
CHAMPIONING FAMILY BUSINESS ISSUES TO INFLUENCE PUBLIC POLICY: EVIDENCE FROM AUSTRALIA
}

\author{
Justin B. Craig, Ken Moores
}

\begin{abstract}
This paper proposes a strategy for the family firm sector to gain the attention of policy makers. The strategy builds through influencing social expectations, creating political issues, developing legislative actions which are subsequently implemented and regulated. To achieve this, we suggest that the family business sector must achieve salience as a community's definitive stakeholders in which capacity they possess, or are perceived to possess, attributes of power, legitimacy and urgency. Propositions are advanced consistent with developing these attributes that collectively build a policy pathway from the societal benefits that family firms can provide by suggesting the building and management of family firm resources to generate optimal outcomes. Experiences from Australia to illustrate the introduced processes are included.
\end{abstract}

Key words: Family business; life cycle; issue management; stakeholder salience; public policy; Australian case study

It is impossible to ignore family business. This business rubric permeates, and contributes stoically to, the economic and social well-being of every society. In the USA, family businesses are estimated to account for up to $49 \%$ of GDP and $78 \%$ of new job creation (Astrachan \& Shanker, 2003) with these figures being reflective of most developed countries around the world. Considerable evidence suggests that family businesses generally out perform their non-family counterparts using a variety of metrics (e.g., Dibrell \& Craig, 2006; McConaughy, Matthews, \& Fialko, 2001). Anderson and Reeb (2003) confirm that when family members serve as the CEO, financial performance is better than with CEOs from outside the family, and that this effect is even more pronounced when founders are still active; supporting that family ownership is an effective organizational form.

However, despite the fact that it is estimated that family business makes up approximately $80 \%$ of all business globally, it is only recently that scholars have paid more than a cursory glance to family business as a research pursuit. Though this ignorance is being addressed and family business research is gaining significant traction in academic journals and, with that, overdue legitimacy, in the absence of an accepted framework, interpreting research results to influence public policy, with few notable exceptions, ${ }^{1}$ is still very much in its infancy (Craig, Moores, Howorth, \& Poutzouris, 2009). Representations that have been made to decision makers have been constrained by this developing, though burgeoning, academic field that, until recently, has lacked depth in terms of theoretical foundations. Alternatively, research that has been presented to support any policy-related arguments usually point to one area of interest (often taxation related) and thus, for the sake of parsimony and maximum impact, champions veer away from an inclusive theory-driven approach.

\footnotetext{
${ }^{1}$ Gallo in Spain; EEC representation; UN representation as a result of GEM
} 
At the Australian Centre for Family Business, we have for 15 years worked with policy decision makers at Australia's three levels of government to seek further acknowledgement of, and support for, the unique challenges facing Australia's largest business sector. In this paper, we present, using accepted theoretical frameworks and proven best practice in the area of family business, highlights from Australia that have assisted stakeholders in influencing public policy. We acknowledge up front that the framework we introduce is not a panacea and encourage readers to interpret the framework and the associated discussion in the context of their unique cultural and national situations.

\section{Championing Family Business Issues}

Marx (1986, 1990), drawing parallels with the strategy literature, suggests that public issues have an identifiable life cycle. Gaunt and Ollenburger (1995) provide further support and claim that "no matter how issues are classified most agree that issues have a lifecycle and their development can be predicated according to this cycle" (p. 205). Subsequently, using this frame, we suggest that family business issues will progress from firstly being motivated by social expectations, to being something worthy of political, then legislative action, and ultimately through to implementation and social control. This, we further contend, enables us to identify a bona fide strategy that will assist those championing family business issues to steward their claims through the bureaucratic maize. Our focus in this paper will be the first two stages of the Marx cycle (i.e., social expectations and political action) as it is during these early phases that effective integration of public issues management and strategic planning can be accomplished. Significantly, once a public issue passes into the latter phases of the cycle (legislation and social control), the opportunity for effectively integrating private and public goals is lost (Marx, 1986).

It is widely known and accepted that family businesses provide much needed economic and social oxygen to the vast communities they serve. What is not as well known, or at least well understood by society, is that these businesses have unique issues, where we define an issue being created "when one or more human agents attaches significance to a situation or perceived "problem"” (Crable \& Vibbert, 1985: 5; in Gaunt \& Ollenburger, 1995: 204). While it is true that family businesses are beginning to capture the interest of researchers worldwide, they (i.e., their issues) have yet to attract the attention of policy makers. In the main, for example, policy makers have focused on addressing them (their issues) in concert with those of the small and medium sized enterprises (SMEs) sector believing that this focus will simultaneously address the needs of family owned and operated businesses. Notwithstanding the fact that the majority of family firms are SMEs there are large family firms in all parts of the world sharing many of the concerns as their SME counterparts. The issues, we suggest therefore, transcend size. As such a firm-size driven policy agenda will fail to address those issues unique to family firms. Supporting that policy makers should view the family business sector as distinctive from these other sectors with issues of its own, Windsor (2002) claims: "There is no such thing in political action as the business sector. There are important cleavages between large corporations and small-medium businesses, as well as among different types of businesses and industries" (p. 383). Highlighting the differences between, and the challenges faced by, business families will elevate their societal expectation status and provide the impetus for political action (where political action is defined as the activity by which an issue is agitated or settled (Banfield, 1955, in Windsor, 2002). 


\section{Raising Societal Expectations and Activating a Political Response}

Importantly, it is vital that issue champions take an unbiased view of the political process. For example, there is benefit in appreciating that "it is conceivable that politicians and bureaucrats operate like entrepreneurs rather than simply being pressure responders. Politics is essentially 'an entrepreneurial function' in arranging a system of agreements through provision of incentives or inducements, positive or negative." (Banfield 1955: in Windsor, 2002: 393). Regardless, governments, like any organization, are coalitions of individuals and organized sub-coalitions (Cyert \& March, 1963) in which policy makers (politicians and bureaucrats) reconcile divergent interests by making strategic decisions and allocating resources in a manner that is most consistent with the claims of all stakeholders. As such, those involved in the political process in democratic systems, universally understand that they are at the mercy of the constituents they serve and by whom they have been elected. They also understand that the system is such that there is in place an alternative government, or group of political parties, whose role is to ensure the elected group is kept accountable for their actions. An integral part of this process is the need for unbiased and independently gathered evidence of the need for, in the current context, changes to policy.

We suggest, therefore, that it is incumbent upon issue champions who are tasked with bringing forth, and stewarding, family business issues in the political arena, that they understand the need to establish the societal benefits of this sector through the collection of indisputable evidence of their considerable societal contribution. Hence we propose:

Proposition 1: To effectively influence public policy, it is important for issue champions to raise societal awareness of the family business sectors' societal and economic contribution, and their unique issues, by facilitating the collection and dissemination of indisputable evidence.

Proposition 2: To effectively influence public policy, it is important for issue champions to equip themselves with indisputable evidence of the family business sectors' economic and societal contribution, and their unique issues, when approaching policy decision-makers.

\section{Stakeholder Identification and Salience}

Consistent with our approach to use bona-fide frames to guide the engagement of dialogue with the policy-maker community, we enlist Mitchell, Agle and Wood's (1997) theory of stakeholder identification and salience in which stakeholders are described by their possession of one or more of three relationship attributes: power, legitimacy, and urgency. By combining these attributes Mitchell et al. (1997) generate a typology of stakeholders and then propose how these stakeholders have salience for firm level managers. We propose an adaptation of their approach by suggesting this categorization of stakeholder status is indeed appropriate to family firms in their efforts to be salient for policy makers in which the addition of urgency to power and legitimacy move the model from static to dynamic.

In the macro context in which we are seeking to employ these ideas the fundamental question is: Which group of stakeholders is deserving or requiring the attention of policy 
makers? A stakeholder in this sense is any group who can affect or is affected by the achievement of the government's objectives. In our context, power is a relationship among social actors in which one social actor, the family business sector, can get another social actor, the government, to do something that the government would not have otherwise done. The bases of this power can be coercive, utilitarian or normative. Legitimacy is a generalized perception or assumption that the actions of entity are desirable, proper, or appropriate within some socially constructed system of norms, values, beliefs and definitions. The bases for legitimacy are individual, organizational, and societal. While urgency is the degree to which stakeholder claims call for immediate action. The bases for urgency are time sensitivity and criticality. Finally, salience is the degree to which policy makers in our case give priority to competing stakeholder claims. Mitchell et al. (1997) further introduce how stakeholders can be defined in terms of these attributes (power, legitimacy, and urgency) with those identified as having only one attribute being labeled latent stakeholders; those with two attributes are expectant stakeholders; while those with all three attributes are definitive stakeholders.

Pertinent to this discussion, the perspective of policy decision-makers is vital. It is they who determine which stakeholders possessed variously of power, legitimate, and urgent attributes, are salient. That is, it is their perceptions of the stakeholder attributes that is critical to how they view stakeholder salience. As such these characteristics moderate the relationship between attributes (power, legitimacy, urgency) and salience.

Figure 1 illustrates Mitchell et al.'s (1997) classes in their stakeholder salience thesis. The low salience classes (i.e., the latent stakeholders) are identified by their possession, or attributed possession, of only one of the three attributes. These are labeled dormant, discretionary, or demanding. The moderately salient stakeholders are identified by their possession or attributed possession of two of the attributes and are identified as being dominant, dangerous or dependent. Because they are stakeholders who "expect something" these combinations are categorized as being expectant stakeholders. The combination of all three attributes (including the dynamic relations among them) is the defining feature of highly salient stakeholders referred to as definitive stakeholders. Nonstakeholders are also identified as a class.

Figure 1: Classes of Stakeholders (Mitchell et al. 1997)

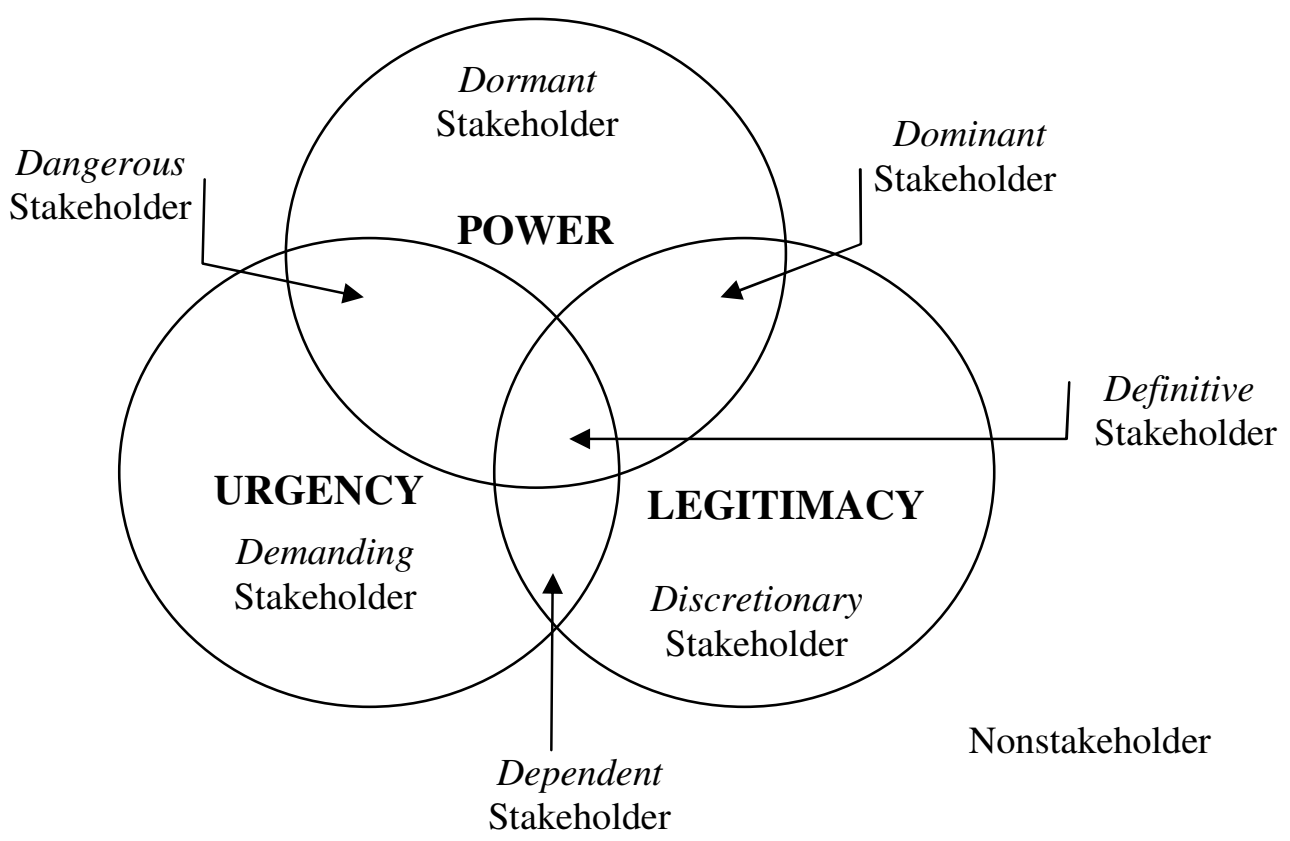


Consequently, for family business issue champions to be effective, given the importance of identifying, and distinguishing the salience of, stakeholders, and how they interact, we propose:

Proposition 3: To effectively influence public policy, it is important for issue champions to understand that stakeholder salience is a dynamic process that can be interpreted in terms of the attributes of power, legitimacy and urgency and are able to strategically identify their concerns in terms of attributes of stakeholders when approaching policy decision-makers.

Proposition 4: To effectively influence public policy, it is important for issue champions to understand the salience of various stakeholder groups and are able to identify their concerns as having the attributes (power, legitimacy, urgency) that define stakeholder salience when approaching policy decision-makers

\section{Case Study: The Australian Experience -The Why, What, When and How.}

Our aim in this paper is to introduce a discussion that proposes how a strategy for the family firm sector will help to gain the attention of policy decision-makers. The strategy builds through initially raising social expectations, activating political responses, and later developing legislative actions which are subsequently implemented and regulated. To achieve this, we suggest that the family business sector must achieve salience as a community's definitive stakeholder in which capacity they possess, or are perceived to possess, attributes of power, legitimacy and urgency.

We have alluded above to the notion that for strategies to effectively influence public policy they should not be looked at in isolation. That is, an intentional collaborative effort is required across a multiple of fronts in order to increase the chance that policy decisionmakers will seriously consider addressing family business-related issues. Fundamental to this is the notion that in order to effect policy change, stakeholders generally, and policy decision-makers in particular, must first know why a change is needed and what it is they are setting out to achieve by any change. Concurrently, how and when processes need to be understood by the issue championing coalition. In this section we advance suggested strategies based on our Australian experience and introduce a further series of propositions to guide future research.

Driving the argument presented above is the assumption that society and policy decisionmakers need to be made familiar with not only the economic contribution of the family business sector in their respective constituencies, but also their unique challenges (as introduced in our Propositions 1 and 2). In Australia, to facilitate this, family business specific questions were added to the national Business Longitudinal Survey (BLS). The BLS conducted by the Australian Bureau of Statistics (ABS) on behalf of the federal government was designed to provide information on the growth and performance of 
Australian employing businesses, and to identify selected economic and structural characteristics of these businesses.

The ABS Business Register was used as the population frame for the survey, with approximately 13,000 business units being selected for inclusion in the first (1994-95) mailing of questionnaires. For the 1995-96 survey, a sub-sample of the original selections for 1994-95 was chosen, and this was supplemented with a sample of new business units added to the Business Register during 1995-96. The sample for the 1996-97 survey was again in two parts. The first formed the longitudinal or continuing part of the sample, comprising all those remaining live businesses from the 1995-96 survey. The second part comprised a sample of new business units added to the Business Register during 1996-97. A similar procedure was followed for the 1997-98 survey. Approximately 6,400 business units were surveyed in each of 1995-96, 1996-97 and 1997-98. ${ }^{2}$

Data collection in the BLS was achieved through self-administered, structured questionnaires containing essentially closed questions. Copies of the questionnaires used in each of the four annual collections can be obtained from the ABS. The questionnaires were piloted prior to their first use, and were then progressively refined in the light of experience after each collection. As well as on-going questions, each questionnaire also included onceoff questions dealing with certain matters of policy interest to the federal government at the time of the collections. Various imputation techniques, including matching with other data files available to the ABS, were employed to deal with any missing data. Because information collected in the BLS was sought under the authority of the Census and Statistics Act 1905, and thus provision of appropriate responses to the mailed questionnaires could be legally enforced by the Australian Statistician, response rates were very high by conventional research standards - typically exceeding 90 per cent.

As is evident, the inclusion of family business questions on a national longitudinal business survey enabled the collection and objective analyses of rich data that could help establish the legitimacy attributes of the family business sector ${ }^{3}$. Hence, we are able to propose:

Proposition 5: To effectively inform policy decision-makers as to the legitimacy of the family business sector, methodologically sound, preferably longitudinal, data should be collected, and objectively interpreted, of a national sample.

Proposition 6: Policy is more likely to be effectively influenced if policy decisionmakers are properly informed of the economic and social contributions of family business.

\footnotetext{
${ }^{2}$ All business units in the Australian economy were included within the scope of the BLS except for the following: Non-employing businesses and all government enterprises. Businesses classified to the following Australian and New Zealand Standard Industrial Classification (ANZSIC) Divisions: A - Agriculture, forestry and fishing; D - Electricity, gas and water supply; J - Communication services; M - Government administration and defense; N - Education; O - Health and community services. ANZSIC Sub-Divisions 96 (Other services) and 97 (Private households employing staff), and ANZSIC Groups 921 (Libraries), 922 (Museums) and 923 (Parks and gardens), were also excluded from the BLS. The BLS did not employ completely random samples. The original population (for 1994-95) was stratified by industry and business size, with equal probability sampling methods being employed within strata. Further stratification by innovation status, exporting status and growth status took place for the 1995-96 survey. The ABS has calculated a system of weights, reflecting the sample fractions used for each stratum, which can be used to estimate population parameters from the BLS data.

${ }^{3}$ Importantly, data collection opportunities that include questions directed at informing policy decision makers need to be realized on an ongoing basis. To this end, currently, the ACFB is working with FBA and KPMG to collect information from a national sample of family businesses.
} 
Family business as an interest group has the potential to increase their power by concentrating their interests (McDonough, 2000). However, due to the multiple factions and the dynamic nature of concerns, interest group power is a complicated issue and it is very difficult to detect how much influence groups actually have (Windsor, 2002: 392). Regardless, relevant to our context, Page and Simmons (2000) attribute substantial 'political power' to business, both major corporations and small businesses.

To effect public policy change, using Mitchell et al.'s (1997) classes of stakeholders, there is a need to move family businesses from latent to expectant stakeholders. To do this in Australia, subsequent to a national study in 1992 (prior to the aforementioned BLS), a network of family business operators, academics, advisors and government representatives established what morphed into a non-for-profit organization known as Family Business Australia (FBA). With a formal organizational structure that includes formal governance and a Chief Executive Officer and representation in all States, this body is responsible for the strategic planning and implementation of the mission to lift the profile and lobby on behalf of the country's family business community.

FBA has as one of its espoused objectives to advocate on behalf of its family business constituency. To date this endeavor is still in its infancy but it has begun to build its power to reinforce the legitimate claims of the sector as a societal stakeholder through engagement with government representatives. A recent specific national achievement has been FBA's advocacy concerning disclosure requirements for private companies with more than 50 shareholders. Many of today's policy pronouncements and corporate governance requirements are predicated on a market model of governance in which adequate disclosure is necessary to keep stakeholders informed. However the real circumstances of most family firms with higher levels of shareholder activism call for an alternative control governance model for which less onerous disclosure requirements would suffice (Lane, Astrachan, Keyt, \& McMillan 2006). FBA presented a case to a recent Parliamentary Joint Committee on Corporations and Financial Services. While the terms of reference for the Committee were primarily directed at the public listed corporate sector, FBA took the opportunity to suggest that their terms should include unlisted companies, including unlisted family companies (UFCs) given their economic importance to Australia. FBA advocated that the requirement for private companies with more than 50 shareholders (section 113 (1) of the Corporations Act) being subjected to more onerous disclosure requirements be changed to permit companies with less than 300 shareholders to remain small or large proprietary companies with less, if their shareholders so determine. FBA argued in its submission that "This (section 113) is one of the more unpopular provisions of the Australian corporate regulatory regime. UFCs are known to adopt a range of shareholding arrangements to avoid the requirement to convert from unlisted proprietary to unlisted public company status. These include: minimum shareholding limits and otherwise independent shareholdings being held jointly under various ownership, or beneficial ownership structures. Alternatively strategies such as 'no dividend' or 'low dividend' policies are employed to create shareholder dissatisfaction and help effect shareholder buy-outs. Such policies often cause family conflict and importantly, from an economic viewpoint, exiting shareholders are no longer available to contribute capital to the business and the funds committed to equity purchases are no longer available for investment in corporate growth". 
The Committee in part accepted FBA's advocacy on this matter and accordingly has recommended that the government enact legislation to amend section 113 of the Corporations Act to raise the limit for shareholders in a proprietary company to 100 . Specifically the committee is also of the view that the broader issue of the framework for regulating small, closely held companies needs to be reviewed. The one-size-fits-all approach of the Corporations Act may be appropriate for large publicly listed companies with a diverse shareholder base with a considerable equity investment, but it places a significant regulatory burden on small companies and not-for-profit organisations for which the protection offered to investors by the Corporations Act is not as appropriate. The government should therefore begin to investigate an alternative regulatory framework for small incorporated companies and not-for-profit organisations (Recommendation 10). While still a size-based requirement this outcome has recognized that the activism of family shareholders (the numbers of which grow across generations) can mitigate against the necessity for detailed disclosure.

At a regional level, the South Australian (State) Government has recognized the significance of the family business sector by appointing a family business authority within its Thinker in Residence in 2007. Apart from moving to implement a range of recommendations made in his report the South Australian Government has also appointed a Development Officer for Family Business within its bureaucracy.

In Mitchell et al.'s (1997), framework, the above are examples of how coalitions working in unison move dormant stakeholders to expectant stakeholders by combining legitimacy and power attributes, and enables us to propose:

Proposition 7: To effectively influence public policy, it is necessary to move from latent stakeholder to expectant stakeholder category using a coalition that includes family business representatives, family business advisors, respected family business scholars and informed bureaucrats with clearly articulated objectives.

Proposition 8: As family firms usually outlive incumbent political parties, to effectively influence public policy that is sustainable over time, the coalition must take an inclusive approach and enlist the support of all political parties.

These propositions essentially guide issue champions in their quest to build a case for family businesses to be viewed as legitimate and powerful community stakeholders. Augmenting this case and providing a level of specificity as to what needs to be incorporated in any policy proposals will be evidence-based material to secure enhancement of the sector's resource base.

Further, any argument needs to be driven by scientific inquiry. In the case of family business, accepted concepts driven by, for example, resource based view of the firm (RBV) scholars (e.g., Habbershon, Williams, \& McMillan, 2003) and the work of Miller and Le Breton-Miller (2003) provide an accepted theoretical foundation from which to argue. A clear understanding of the distinct distinguishing factors related to, and challenges facing, family business is required. Knowledge of the physical-, human-, organization-, and process-related resource capabilities of family firms provides a succinct framework within which to work. As well, knowledge of the priorities related to command, connection, 
community, and continuity that family firms have been able to manage for the long term are required in order to shape a strategy that will attract decision-maker support.

Reinforcing then, a central tenet of our discussion has been the need to inform discussion using established frames or scientific (i.e., theory-driven) evidence. Staying true to this approach, we suggest that the principles of RBV, which view the firm as a combiner of heterogeneous and imperfectly mobile resources (Penrose, 1959; Wernerfelt, 1984), and that has wide acceptance in its application to family businesses, can be used to position the unique challenges as urgency attributes. Specifically, RBV incorporates the complex, idiosyncratic, and unique nature of (in our context) a family firm's internal processes and intangible assets, including the values, beliefs, and symbols, and interpersonal relationships possessed by individuals or groups (Barney, 1991). As such, RBV focuses on an analysis of the nature, characteristics and potential of a firm's resource base and assumes each firm's internal resources and capabilities are heterogeneous, which leads to a competitive advantage (Barney 1991).

However, though resource heterogeneity is a necessary condition of RBV, it is not a sufficient condition for competitive advantage. Barney (1991) identified that in order to contribute optimally to firm sustainability, resources must be valuable, rare, imperfect imitable, and non-substitutable (VRIN). Wernerfelt (1984) defined resources as anything which could be thought of as strength or weakness of a firm and at any given time could be defined as those (tangible and intangible) assets which are tied semi-permanently to the firm.

RBV has particular relevance to family business research (Habbershon \& Pistrui, 2002). Notably, using the RBV framework, Sirmon and Hitt (2003) argue that family businesses evaluate, acquire, shed, bundle, and leverage their resources in ways that are different from businesses that are not family owned. In the family business context, the term "familiness" has been introduced to define the unique bundle of idiosyncratic resources and capabilities existing in family firms. As such, familiness is one of the intangible factors that make the family business different to their corporate equivalents, and can be a point of difference that contributes to competitive advantage. Conversely it can have a stifling effect and inhibit growth (Craig \& Lindsay, 2002). Specifically, Habbershon, Williams and McMillan (2003) propose that familiness-related resources and capabilities can present both a source of advantage as well as a source of disadvantage to the firm. Wealth-creating performance for family-influenced firms is a function of the "distinctive" familiness ( $\mathrm{f}+$ factor) while "constrictive" familiness (f- factor) hold the potential to constrain the firms competitiveness. Importantly, familiness influence changes orientation due to contextual influences within the family business including the organizational and family life cycle (Habbershon, 2006). Furthermore, a contextual factor that encourages an $\mathrm{f}+$ factor in one family firm may encourage an $\mathrm{f}$ - factor in another. As a consequence, family firms in pursuit of sustainable competitive advantage vis-à-vis their distinctive familiness need to understand and manage the conditions and contextual factors under which familiness-based resources and capabilities maintain their $\mathrm{f}+$ advantage for the firm.

We further argue governments are in a position to assist the family business sector by helping in the development of resources to ensure their sustainability across generations. But to do that, irrefutable evidence is required of the characteristics of long run family businesses. One source of these characteristics is supplied by Miller and Le Breton-Miller 
(2003). In Managing for the Long Run, these noted scholars reason that, because of their long-term strategic outlook, family businesses tend to favor strategic orientations built around customer relationships over those built on market transactions. Such long lived family firms emphasize certain key priorities that resonate with societal expectations and political aspirations for steady growth and prosperity, long term employment prospects, and corporate social responsibility. Long lived family firms achieve their continuity by pursuing their dream whereby they commit enduringly and passionately to a substantive mission - to do something important exceptionally well - and invest deeply and for the long run in competencies needed to attain that mission. Furthermore, to realise their mission thriving family firms insist on building a sense of community by uniting the tribe. They build cohesive, clan-like teams that embrace strong values that rally people around what is important they socialise staff to assure that these values will prevail, and they pamper employees to elicit loyalty, initiative, and collaboration. For such firms, bureaucratic rules and financial incentives are secondary. This sense of community is reinforced by their connection to others through being good neighbours. Many great family firms cherish enduring, open-ended, mutually beneficial relationships with business partners, customers, and the larger society. These relationships vastly exceed the time span, scope, and potential of periodic market or contractual transactions. Finally, family business leaders enjoy a command capacity that empowers them to adapt their businesses with freedom through discretion to act independently - quickly and in original ways - often to renew or adapt the firm. Typically they work with an empowered top team whose members are similarly free to communicate openly and make decisions.

Accordingly when governments are seeking to grow their economies and increase the living standards of their citizens, there is an urgent imperative to develop policies that create environments in which families firms can be supported. To create environments that sustain family firms, governments will need to formulate and implement policies that enhance the resource base of family businesses that foster the development of best practice. This discussion leads us to propose:

Proposition 9: To effectively influence public policy, an accepted theoretical frame (e.g., RBV which enables the identification of the VRIN resources of sustainable families) should be clearly articulated to policy decision-makers.

Proposition 10: To effectively influence public policy, the priorities of family firms that manage for the long run should be clearly articulated to policy decisionmakers.

\section{Conclusion}

We suggest in this paper that to effectively influence public policy related to the unique issues facing families in business it is necessary to first understand the evolution of a public policy issue. In this instance we concentrated on how to raise societal expectations and activating a political response. We argued that fundamental to the raising of societal expectations is the collection of robust data. That in place, we shared our experience that if this data is used appropriately there is the real potential to build a basis for legitimacy. We stress that this is necessary but not sufficient to achieve the status of an expectant stakeholder. To achieve this level, we contend, requires the acquisition of power which can be attained through galvanizing a coalition of family business representatives, family 
business advisors, and respected family business scholars. From this platform achieving definitive stakeholder status requires policy makers to accept the urgency of the claims made by the issue championing coalition.

To this end, we distilled a series of propositions from several valid frameworks to enable further conversations by researchers and practitioners. We included evidence from Australia's experience to illustrate details related to the why, the what, the when and the how processes needed to be understood and mobilized to move latent stakeholder groups to a point where they, and their issues, are more powerful, more legitimate, and more urgent, and ultimately, therefore, definitive stakeholders. 


\section{References}

Anderson, A. R., Reeb, D. M. (2003) Founding Family Ownership and Firm Performance: Evidence from the S\&P 500, Journal of Finance, vol. 58 no. 3, pp.1301-1327.

Astrachan, J. H., Shanker, M. C. (2003) Family Businesses' Contribution to the U.S. Economy: A Closer Look. Family Business Review, vol. 16 no. 3, pp. 211-219.

Barney, J. B. (1991) Firm Resources and Sustained Competitive Advantage, Journal of Management, vol. 17 no. 1, pp. 99-120.

Business Longitudinal Survey Confidentialised Unit Record File - 1994/95, 1995/96, 1996/97 and 1997/98, Australian Bureau of Statistics, Canberra.

Craig, J. B., Lindsay, N. (2002) Incorporating the Family Dynamic into the Entrepreneurship Process, Journal of Small Business and Enterprise Development, vol. 9 no. 4 , pp. 416-430.

Craig, J. B., Moores, K., Howorth, C., Poutzouris, P. (2009) Family Business Research At A Tipping Point Threshold, Journal of Management and Organization, vol. no. 3., forthcoming.

Cyert, M. R., March, J. G. (1963) A Behavioral Theory of the Firm. NJ: Prentice Hall, Englewood Cliffs.

Dibrell, C., Craig, J. B. (2006) The Natural Environment, Innovation, and Firm Performance: A Comparative Study, Family Business Review, vol. 14 no.4, pp. 275288.

Gaunt, P., Ollenburger, J. (1995) Issues Management Revisited: A tool that deserves another look, Public Relations Review, vol. 21 no 3, pp. 199-210.

Habbershon, T. G. (2006) Commentary: A Framework for Managing the Familiness and Agency Advantages in Family Firms, Entrepreneurship Theory and Practice, vol. 30 no. 6, pp. 879-886.

Habbershon, T. G., Pistrui, J. (2002) Enterprising Families Domain: Family-Influenced Ownership Groups in Pursuit of Transgenerational Wealth, Family Business Review, vol. 5 no. 3 , pp. 223-237.

Habbershon, T. G., Williams, M., MacMillan, I. C. (2003) A Unified Systems Perspective of Family Firm Performance, Journal of Business Venturing, vol. 18 no. 4, pp. 451465.

Lane, S., Astrachan, J., Keyt, A., McMillan, K., (2006) Guidelines for Family Business Boards of Directors, Family Business Review, vol. 19 no. 2, pp. 147-167.

Marx, G. (1986) Integrating Public Affairs and Strategic Planning, California Management Review, vol. 29 no. 1, pp.141-147. 
Marx, G. (1990) Strategic Planning for Public Affairs, Long Range Planning, vol. 23 no. 2, pp. 3-8.

McConaughy, D. L., Matthews, C. H., Fialko, A. S. (2001) Founding Family Controlled Firms: Performance, Risk, and Value, Journal of Small Business Management, vol. 39 no. 1 , pp. 31-49.

McDonough, J. E. (2000) Experiencing Politics: A Legislator's Stories of Government and Health Care. Berkeley, CA: University of California Press, New York: Milibank Memorial Fund.

Miller, D., Steier, L., Le Breton-Miller, I.. (2003) Lost in Time: Intergenerational Succession, Change, and Failure in Family Business, Journal of Business Venturing, vol. 8 no. 4 , pp. 513-531.

Mitchel, R. K., Agle, B. R., Wood, D. J. (1997) Toward a Theory of Stakeholder Identification and Salience: Defining the Principle of Who or What Really Counts, Academy Management Review, vol. 22 no. 4, pp. 853-886.

Page, B. I., Simmons, J. R. (2000) What Government Can Do: Dealing with Poverty and Inequality. Chicago, IL: University of Chicago Press.

Penrose, E. T. (1959) The Theory of the Growth of the Firm. 3rd Edition: Oxford University Press, New York.

Sirmon, D. G., Hitt, M. A. (2003) Managing Resources: Linking Unique Resources, Management, and Wealth Creation in Family Firms, Entrepreneurship Theory and Practice, vol. 27 no. 4, pp. 339-358.

Wernerfelt, B. (1984) A Resource-Based View of the Firm, Strategic Management Journal, vol. 5, pp.171-180.

Windsor, D. (2002) Public Affairs, Issues Management, and Political Strategy: Opportunities, Obstacles, and Caveats, Journal of Public Affairs, vol. 1 no. 1, pp. 382415. 